\title{
Spanish/English Bilingualism and \\ Finiteness Acquisition
}

Damaris Castro García

Universidad Nacional, Costa Rica

\section{RESUMEN}

Se of rece un análisis del lenguaje de una niña bilingüe (Mina) con la intención de comprobar la teoría de Wexler quien dice que el lenguaje de los niños presenta un período de uso 'opcional de formas verbales infinitivas' en contextos en los que adultos no las usarían. Se presenta importante información relacionada con el tema y se analizan las muestras de idioma para concluir que sí hay evidencia para la existencia de dicho período en ambos idiomas: éste se expresa en inglés a través de formas infinitivas y en español en verbos que varían aspectualmente y que aparecen en predicados que no tienen concordancia con su sujeto. Además se comparan los resultados de varios estudios de diferentes lenguas.

\section{Abstract}

This paper presents the analysis of the speech of a bilingual child (Mina) in order to determine if the 'Optional Infinitive Stage' (OI) (Wexler) is present in her language production at this stage of language development $\left(\mathrm{S}_{0}\right)$. The first part presents important background information. Then, the English and Spanish data are analyzed to conclude that the Optional Infinitive stage is expressed both in Spanish and in English through different mechanisms, Root Infinitives in English and 'aspectually variable' verbs that appear as 'misagreeing' predicates in Spanish.

Palabras clave: Adquisición, Aktionsart, aspecto, bilingüismo Keywords: Acquisition, Aktionsart, bilingualism

I E-mail: dcastro@una.ac.cr. 


\section{Literature Review and Preliminary Analysis}

Many research studies have been devoted to investigating the features of the verbal forms that children produce in their early stages of language production. Wexler shows that children use infinitive forms in the predicate position of root clauses as part of their grammar, while adults would only use inflected forms in these environments. ${ }^{2}$ Through the study of children's grammar forms, researchers try to establish the components that make up Inflection (Infl) in children at this age (roughly $1 ; 7,0$ to $2 ; 6,0)^{3}$ which could also bear information on the content of Universal Grammar (UG) at initial stages of language acquisition $\left(\mathrm{S}_{0}\right)$.

Several theories discuss the content of Infl at stage $S_{0}$. For Poeppel and Wexler, Infl is fully specified at this stage and the absence of overt marking is only due to reasons other than syntactic factors, as would be the case of phonological and morphological issues. ${ }^{4}$ For Deprez and Hyams, at this stage there is still no specification in Infl for morphological and syntactic processes; thus its functions cannot be put into practice. ${ }^{5}$ Yet a third theory posited by Radford argues that children's use of infinitives reflects the lack of tense and agreement specifications in their grammar; that is, that Infl is missing at this stage of language acquisition. ${ }^{6}$

$\overline{2} \quad$ Kenneth Wexler. "Optional Infinitive. Head Movement and the Economy of Derivations." Verb Movement, eds. N. Hornstein and D. Lightfoot (Cambridge: Cambridge University Press, 1994) 305-350.

3 Indicating years: months, days.

4 D. Poeppel and K. Wexler, "The Full Competence Hypothesis of Clause Structure in Early German," Language, 69 (1993) 1-33.

5 Viviane Deprez, "Underspecification, Functional Projections and Parameter Setting," Syntactic Theory and First Language Acquisition, eds. B. Lust. M. Suñer and J. Whitman (Hillsdale, NJ: Lawrence Erlbaum, 1994) 249-271. Nina Hyams, "Underspecification of Functional Categories in Early Grammar," Generative Perspectives in Language Acquisition, ed. Harald Clahsen (Amsterdam: John Benjamins, 1996) 91-127.

6 A. Radford, Symactic Theon and the Acquisition of English Symtax (Oxford: Oxford Blackwell, 1990). 
There is a relation between the availability of Infl in early child syntax and the knowledge of finiteness at $S_{0}$. For Wexler, finiteness can be observed in children's grammar when they appropriately use tense and agreement markings on their verbal predicates; i.e., in English, the "s" in third person singular represents the features [+present, +third person, +singular]. ${ }^{7}$ For Wijnen, on the other hand, a finite verb is that which contains "a suffix indicating tense and

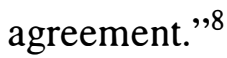

\section{Wexler's Approach}

Wexler's concept of “Optional Infinitive Hypothesis" refers to children's optional use of Root Infinitives (RIs) in various languages. Assuming, as does Pollock, that Infl is split into tense and agreement projections, we would then see these functional projection properties reflected in the correct forms of verbs (either finite or non-finite). ${ }^{9}$ Furthermore, it is important to consider the role that the feature "strength" plays as part of Infl. When Infl is "strong" the verb is attracted out of the Verbal Phrase (VP), as observed in Spanish and French (languages with a rich paradigm featuring a wide range of agreement forms). When the feature "strength" in Infl is weak, on the other hand, verbs are not attracted out of the VP and inflections lower onto the verb, as in English. ${ }^{10}$

Wexler centers his study on the stage of children's acquisition at which they optionally use infinitive predicates in root contexts. His analysis is based on the following languages: German, Dutch, Swedish, Norwegian (Germanic languages) and French (the only Romance language in his study). He argues that there is an Optional Infinitive stage and that the evidence for finiteness acquisition comes from the

\footnotetext{
$7 \quad$ Wexler, 307.

8 Frank Wijnen, "Temporal Reference and Eventivity in Root Infinitives," MITOccasional Papers in Linguistics, 12 (1996) 1.

9 J. Pollock, "Verb movement, Universal Grammar and the Structure of IP," Linguistic Inquiry, 20 (1989) 365-424.

10 Liliane Haegeman and Jacqueline Guerón, English Grammar (Oxford: Oxford Blackwell, 1999).
} 
children's ability to create $\mathrm{V}^{0}$-to- $\mathrm{I}^{0}$ chains. ${ }^{11}$ The presence of tense and agreement features in the verb forms used by children would reflect the availability of these functional forms in Infl. This would be observed in a different distribution for finite and non-finite root predicates. To support his claim Wexler presents evidence based on English negation and the verbal position in this context, as in the following examples ${ }^{12}$ :

(1)
a. Mary plays baseball
b. Mary play baseball
c. Mary not play baseball
d. *Mary not plays baseball
e. ?Mary does not play baseball

Here Wexler establishes a relation between these data and the Optional Infinitive (OI) stage. He argues that if the grammar of a child exhibits a drop of third person singular $-\mathrm{s}$, it would also lack "do" in medial negation in sentences in which $-\mathrm{s}$ is not part of the verb either. This phenomenon has generally been considered a nonsyntactic process; however, the process could also be related to the OI stage. So a sentence like (1d) is not expected in child production; (1c), on the other hand, represents a sentence that is expected in the child's grammar. Based on this information he draws the conclusion that a connection exists between non-finite predicates and medial negation in the OI stage of English speaking children. Wexler concludes that the fact that they optionally use infinitive forms means that they have not yet acquired tense features nor do they know the different values that Infl can have. ${ }^{13}$ Even when they are not able to handle syntactic tense features, they can still handle the notion of time appropriately. Wexler goes on to argue that according to his

11 Wexler, 307.

12 Wexler, 330-331.

13 Wexler, 338. 
framework, tense is a formal syntactic notion which carries the values [+/-Past], features that are not part of the Time notion, as this is a more cognitive concept. Children could very well assign a correct temporal interpretation to predicates which do not carry finite information.

\section{The "Free Variation" Prediction and Aktionsart}

In his study Wexler proposes that the Optional Infinitive stage features finite and non-finite forms coexisting in free variation. If this is the case, it suggests that these forms coexist in free variation; thus at this stage of child language, there would be no way of establishing correlation between finiteness and Aktionsart, which involves the inherent lexical aspect of verbs. ${ }^{14} \mathrm{~A}$ correlation between stative or eventive predicates and the finiteness of verbs in the child's language would not be expected. This would lead us to the conclusion that children use inflection freely at this stage; this also suggests that we could expect an equal distribution among eventive and stative verbs in finite and non-finite environments as proposed by Gavruseva. ${ }^{15}$ Figures 1 and 2 below present an analysis showing a relation between Aktionsart and finiteness. ${ }^{16}$

Before moving on in the analysis itself, the term Aktionsart deserves to be explained in further detail. Joos defines 'status' verbs as those not compatible with the temporary aspect. ${ }^{17}$ That is, they "reject the time-limited validity of the temporary aspect" and do not represent an event that proceeds but rather a relation between the participant of the action and the situation taking place. Furthermore,

14 For Comrie (1976:6) Aktionsart means "kinds of action" and henceforth it will be used to ref er to differentiate between the aspectual classes of 'eventives' and 'statives.'

15 Elena Gavruseva, "Is There Primacy of Aspect in Child L2 English?" Bilingualism: Language and Cognition, 5 (2), (2002) 109-30.

16 Damaris Castro, Finiteness in Spanish/English Bilingual Acquisition: A Case Study. Master's Thesis, University of Iowa (2002) 12.

17 Martin Joos, The English Verb: Fonn and Meanings (Madison: The University of Wisconsin Press, 1964) 114. 
there is another subdivision in this category: in one group you find verbs that express a 'psychic state'. These are perception verbs and involve intellectual as well as emotional attitudes (i.e., see, hear, believe, know, understand). The second group encloses verbs that express some type of relation and Joos calls them verbs of 'relation' (i.e., have and belong). ${ }^{18}$

Comrie refers to the specifications for eventive and stative verbs. ${ }^{19}$ Stative verbs on the one hand, exhibit stability throughout the process, the different stages of the situation are equal and there is no difference between one point and another in the situation. Their state continues "unless something happens to change the state," and Comrie also, he refers to eventive verbs ('eventives' henceforth) as "dynamic verbs," verbs denoting a difference between one stage and another within the situation, where the situation continues "if it is constantly subject to a new input of energy." The following syntactic and semantic tests can be applied to determine if a verb is stative or eventive. See the following sentences:

a. *I saw him knowing the answer (stative)

b. I saw him writing the answer (eventive)

a. $\quad *$ Know it! (stative)

b. Write it! (eventive)

a. *I finish knowing the answer (stative)

b. I finished writing the answer (eventive)

a. $\quad *$ I know tomorrow (stative)

b. I leave tomorrow (eventive)

18 Joos, 118-119.

19 Bernard Comrie Aspect (Cambridge: Cambridge University Press, 1976) 48-51. 
Wijnen claims that stative verbs cannot appear as the root verb in the complement clause of a verb of perception as is evident in Test $1,(2 \mathrm{a})$; this is not the case for eventive verbs (2b). ${ }^{20}$ Test 2 shows that while eventive verbs can be used as imperatives, as in (3b), statives cannot have this function as (3a) shows. ${ }^{21}$ As a third test, Pustejovsky also points out that stative verbs cannot be used in combination with the verb 'finish' as in (4a). Finally, Joos' tomorrow test indicates that there is no compatibility of stative verbs with the adverb 'tomorrow' as in $(5 \mathrm{a})$, a role that can be played only by some eventive verbs. ${ }^{22}$

\section{Optional Infinitive Stage in Dutch Children}

Wijnen's study focuses on the temporal interpretation of RI and finite forms while considering Wexler's idea of "Acquisition of finiteness" and the eventive vrs. stative distinction (Aktionsart). He also follows Reinchenbach's idea that locates a situation denoted by a predicate (E-time) in a time axis related to a given time reference $(\mathrm{S}$ time or R-time) ${ }^{23}$ Wijnen draws the conclusion that there is a different temporal interpretation for these predicates, as seen in the table below:

Table 1. Finiteness, temporal distribution and Aktionsart

\begin{tabular}{|l|c|c|c|c|c|c|}
\hline & \multicolumn{2}{|c|}{ Past } & \multicolumn{2}{c|}{ Present } & \multicolumn{2}{c|}{ Future } \\
\hline & Eventive & Stative & Eventive & Stative & Eventive & Stative \\
\hline Finite (699) & 10 & 11 & 319 & 338 & 20 & 1 \\
\hline Non-finite (1883) & 64 & 0 & 192 & 2 & 1534 & 91 \\
\hline \multicolumn{1}{|c|}{ Total } & 74 & 11 & 511 & 340 & 1554 & 92 \\
\hline
\end{tabular}

Source: Wijnen (1996) 1-25.

20 Wijnen, 7.

21 J. Pustejovsky, "The Syntax of Event Structure," Cognition, 41 (1991) 47-81.

22 Joos, 118.

23 H. Reichnbach, Symbolic Logic (Bcrkeley, C.A: University of California Press, 1947); E-time refers to Event Time, $S$-time refers to Speech Time, and $R$-Time refers to Ref erence Time. 
Wijnen found that a correlation can be established between specification for tense and Aktionsart. He shows that no specification for tense resulted in different (past, present and future) temporal interpretations. As Table 1 shows, there is a small group of finite verbs with past temporal interpretation. The number of finite stative verbs referring to the future is also very small, with some increment in eventive verbs. Present tense reference, on the other hand, contains the highest number of verbs (both eventives and statives). In regard to non-finite verbs, there is a clear concentration of eventive verbs in all three temporal referents, with a clear major concentration on future referents. Wijnen also found that specification for agreement and tense coincides appropriately with the temporal interpretation and morphological specification. To conclude, this shows a correlation between Aktionsart and tense specification.

\section{The T-chain Notion in Relation to Wijnen's Results}

According to Wijnen's findings, tense features are part of the functional head $\mathrm{T}$, while Time is part of the Complementizer (C) domain. Guerón and Hoekstra support the idea; for them syntactic tense is located in the Tense Phrase (TP) domain in the syntactic representation of a sentence. Time, on the other hand, as part of the $\mathrm{C}$ domain, is in charge of linking predicates to discourse, so that sentences receive temporal interpretation. Aktionsart, as part of V, provides the e-role of the sentence. The following trees represent Wijnen's results. 


\section{Figure $1 .{ }^{24}$ Time: [past, present,}

future]

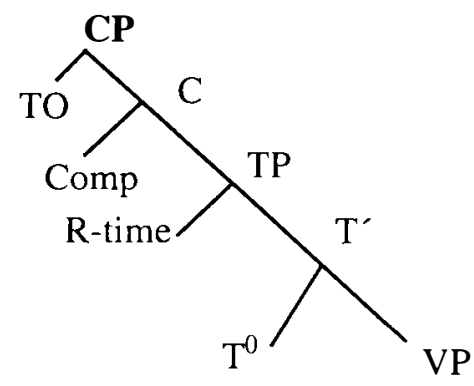

[-tense]

E-time [eventive]

e-role

\section{Figure 2. Time [present]}

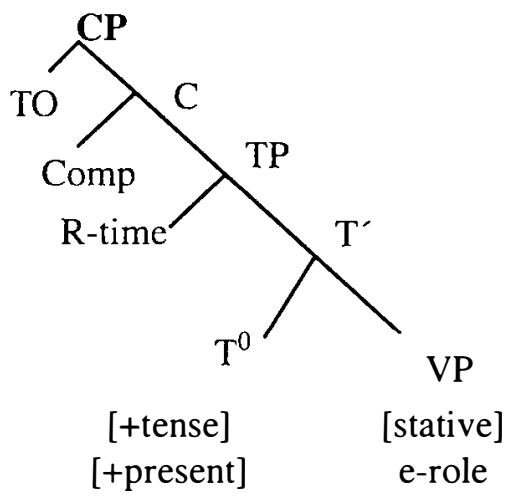

Source: Castro, 2002:12.

In these figures there is a clear representation of what takes place in child grammar during the Optional Infinitive stage. The distribution of the Tense feature and the notion of 'time' are a reflection of this. When there is no specification for tense in the TP domain (Figure 1), free temporal reference takes place and this can be associated with eventive verbs, seen in the Akstionsart classification of stative type of verbs shown in Figure 2. However, when TP is specified for tense, there is a correlation between the reference and its syntactic tense specification. Wijnen's results show that Aktionsart is relevant for the acquisition of finiteness since it is apparent that children distinguish between stative and eventive verbs. This shows that contrary to what Wexler believes, finite and non-finite forms are not in free variation.

Wijnen's affirms that these results reflect the grammatical competence that children have at this stage of their finiteness acquisition

24 Other important terminology: TO: Tense Operator; T P: Tense Phrase; e-role: event role. 
in which the ability to have an eventive/non-eventive contrast is part and parcel of the human language faculty. ${ }^{25}$ For him, the temporal interpretation given to non-finite forms results from a 'deictic interpretation of an event variable (if present). Considering Table 1 again, there is a 'free' temporal interpretation for RIs which means that they do not have a specific value for tense. Wijnen concludes that nonfinite forms are interpreted deictically, an interpretation based on the discourse context. Using Guerón and Hoekstra's ${ }^{26}$ notion of T-chain, a tense operator links a non-finite $\mathrm{V}^{0}$ directly to discourse via $\mathrm{R}$-time in the Comp domain. ${ }^{27}$

\section{Optional Infinitive Stage Analysis in a Bilingual Spanish/ English Child}

The following is an analysis of RIs in the language of a bilingual (English/Spanish) child. Some background information is given as well as an analysis of RIs in the English and Spanish data.

\section{Data and Methodology}

The information comes from the CHILDES database. ${ }^{28}$ It consists of 11 files (6 English, 5 Spanish). The transcriptions are taken from a longitudinal study of Mina (subject's pseudonym). She is the daughter of a Cuban father (non-native English speaker) and a British mother (non-native Spanish speaker); the grandmother intervenes in a few instances also. The data collection started when Mina was 1;9.9, and finished when she was $2 ; 6.21$. The data show variation between recording intervals and between recordings for specific languages. The following table summarizes general information used in the

25 Wijnen, 18-21.

26 Jacqueline Guerón and Teun Hoekstra. "The Temporal Interpretation of predication." Sỵtax and Semantics, 28 (1999) 77-107.

27 Castro, 12-13.

28 B. MacWhinney and C. Snow, "The Child Language Data Exchange System (CHILDES)," Journal of Child Language. 17 (1985) 457-472. 
analysis: the file number, the age of the child at the moment of recording, and the language used by the adults in the interaction. Although the adults in the conversation tried to maintain only one language of interaction, the data analysis showed that files 1, 3 and 6 provide us with information for both languages due to Mina's codeswitching between the languages. The information about finite and non-finite forms will be presented in a subsequent table.

Table 2. General information

\begin{tabular}{|c|c|c|c|c|c|}
\hline \multicolumn{3}{|c|}{ Spanish Files } & \multicolumn{3}{c|}{ English Files } \\
\hline $\begin{array}{c}\text { File } \\
\text { number }\end{array}$ & Date & $\begin{array}{c}\text { Child's } \\
\text { age }\end{array}$ & $\begin{array}{c}\text { File } \\
\text { number }\end{array}$ & Date & $\begin{array}{c}\text { Child's } \\
\text { age }\end{array}$ \\
\hline $\mathbf{3}$ & $05-31-87$ & $1 ; 11.7$ & $\mathbf{1}$ & $04-02-87$ & $1 ; 9.9$ \\
\hline $\mathbf{4}$ & $07-20-87$ & $2 ; 0.25$ & $\mathbf{2}$ & $05-05-87$ & $1 ; 11.4$ \\
\hline $\mathbf{7}$ & $08-29-87$ & $2 ; 2.5$ & $\mathbf{5}$ & $07-28-87$ & $2 ; 1.3$ \\
\hline $\mathbf{9}$ & $11-29-87$ & $2 ; 5.5$ & $\mathbf{6}$ & $08-23-87$ & $2 ; 1.20$ \\
\hline $\mathbf{1 0}$ & $12-26-87$ & $2 ; 6.2$ & $\mathbf{8}$ & $11-26-87$ & $2 ; 5.2$ \\
\hline & & & $\mathbf{1 1}$ & $01-14-88$ & $2 ; 6.21$ \\
\hline
\end{tabular}

Adapted from: Castro, p. 14.

For the analysis, we consider only declarative sentences with verbal predicates. Negatives are considered in the case of Spanish where no auxiliaries are required and the main verbs bear inflection. English negatives are not taken into account because they require an auxiliary which alters finiteness in the predicate sentences. The following five other types of sentences are not part of the analysis: a. clear repetition of adult speech; b. clear repetitions of her own utterances; c. incomprehensible sentences; d. imperative forms; e. mixed utterances containing both English and Spanish words. 
The study covers utterances in which a clear temporal and aspectual interpretation can be determined, based on the detailed description of the acti vities that were taking place during the recordings (the transcriber provides explanations about the activity and the situation). A phonetic transcription of each Spanish and English utterance produced by the child is also available. These phonetic transcriptions provide invaluable information that helps determine the exact phonological segments of the utterance that the child produced.

\section{Optional Infinitive Stage and English Acquisition}

This section searches for evidence of the 'Optional Infinitive' stage in the English data. It presents an analysis of verbal predicates with respect to finiteness features and their correlation with Aktionsart. Table 3 shows a total of 16 finite predicates. Three types of finite predicates are present: progressive forms in present and past (be+ing form), verbs in combination with modals (should and will) and irregular verbs in past tense. The data scarcely present evidence for the third person singular (3PS) and the regular past -ed is absent from the data. There are 49 non-finite forms. Mainly 'bare stems' are present, five participial -ing forms without the auxiliary 'be', and six past participial forms without the auxiliary 'have' are also found. Only 'bare stems', which we consider to be non-finite forms (following Wexler), are considered in this analysis.

Table 3 shows no evidence for the Optional Infinitive stage before file 5. Only non-finite forms (either participial -ing without the auxiliary or bare forms) were used before. File 5 begins to show alternation of finiteness with the presence of the first inflected forms. Consider:

a. '(I) got cake'29
b. 'Mina got cake'

29 Although a "colloquial have' interpretation could be given to these forms, the present count considers this form to have past temporal interpretation. 
Table 3. Finite and non-finite distribution of English verbs

\begin{tabular}{|l|c|c|c|c|}
\hline File & $\begin{array}{c}\text { Finite } \\
\text { predicates }\end{array}$ & $\begin{array}{c}\text { Non-finite } \\
\text { Bare stems }\end{array}$ & $\begin{array}{c}\text { Non-finite-ing } \\
\text { participles } \\
\text { without 'be' }\end{array}$ & $\begin{array}{c}\text { Non-finite past } \\
\text { participles } \\
\text { without 'have' }\end{array}$ \\
\hline File 1 & 0 & 0 & 0 & 1 \\
\hline File 2 & 0 & 0 & 2 & 0 \\
\hline File 3 & 0 & 2 & 0 & 0 \\
\hline File 5 & 2 & 24 & 0 & 0 \\
\hline File 6 & 3 & 5 & 0 & 0 \\
\hline File 8 & 10 & 6 & 2 & 5 \\
\hline File 11 & 1 & 1 & 1 & 0 \\
\hline Total & 16 & 38 & 5 & 6 \\
\hline Percentages & $15 \%$ & $59 \%$ & $7 \%$ & $9 \%$ \\
\hline
\end{tabular}

Source: Castro, p. 17.

This example (6) shows an irregular past form, contradicting Wexler's prediction that the 3PS will appear before past forms. ${ }^{30}$ The fact that these forms are used with different objects serves as evidence that these are not rote constructions, but the child's own productions instead. Even though there is some evidence for the 'Optional Infinitive' stage, we have to consider the proportional difference between finite and non-finite forms. Considering only finite predicates and non-finite verb stems we find 16 finite forms (30\%) as opposed to 38 non-finite forms $(70 \%)$. Recall now Wexler's claim that finite and non-finite forms are in 'free variation' during the 'Optional Infinitive' stage. If this were the case, a more even distribution would be expected; however, the data show that this is not the case: the number of nonfinite forms is twice as large as that of finite forms. This can clearly function as counter-evidence to Wexler's claim.

30 Wexler, 339. 
We now move to the analysis of temporal and aspectual interpretation of non-finite forms in the English data. Table 4 below shows the distribution for non-finite verbs in terms of the temporal reference (past, present, and future) and aspectual interpretation.

\section{Table 4. Temporal distribution of non-finite English forms}

\begin{tabular}{|l|c|c|c|c|c|}
\hline File & Past & Present & Future & Eventives & Statives \\
\hline File 3 & 0 & 1 & 1 & 1 & 1 \\
\hline File 5 & 1 & 11 & 12 & 20 & 4 \\
\hline File 6 & 0 & 4 & 1 & 4 & 1 \\
\hline File 8 & 1 & 3 & 2 & 6 & -- \\
\hline File 11 & 0 & 1 & 0 & 1 & -- \\
\hline Total & 2 & 20 & 16 & 32 & 6 \\
\hline Percentages & $5 \%$ & $53 \%$ & 42 & $84 \%$ & $16 \%$ \\
\hline
\end{tabular}

Adapted from: Castro. p. 19, 20.

No strong correlation ${ }^{31}$ can be established between bare predicates and a specific temporal reference. The presence of three temporal references suggests that Mina does not limit the use of RIs to only one temporal frame. This information matches Wijnen's results (from Dutch) presented earlier in this paper. A clear concentration, however, can be found in present (53\% of the forms) and future (42\% of the forms) temporal interpretations; these temporal frames exhibit a somewhat even distribution. Although the number of instances assigned past temporal interpretation is low, the fact that they are present, which means that the child also has this temporal concept, is still a very significant piece of information. The information in (7)-(9) below shows examples of actual utterances that were produced by the child in each one of the time frame referents mentioned above:

$\overline{31}$ A strong conelation is defined as that reaching $90 \%$ or higher. 
(7) Present interpretation:
a. Mina come back (File 5)
'Mina is coming back'
b. Mina want juice (File 5)

'Mina wants some juice'

(8) Past Interpretation:
a. Rayna touch floor (File 5)
'Rayna touched the floor'
b. This little girl come out (File 8)
'This little girl came out'

(9) Future interpretation:
a. Me take it (File 5)
'I will take it'
b. I close it (File 8)
'I will close it'

Regarding Aktionsart there is a clear concentration of eventive verbs in these data (84\%); they have mainly present and future interpretations. Even though it does not reach 90\%, it is still high enough to propose that RIs in this child's English consists mainly of eventive predicates and have 'free' temporal reference. Statives amount to $16 \%$ of the data and have mainly a present temporal reference. ${ }^{32}$ The stative verbs that occur are 'psychic state' such as 'want' and 'need'; and also verbs of relation such as 'have.' It is also important that in some cases the NP complements are missing, determiners are also missing in all of the examples (i.e.: 'Mina see' for 'Mina wants to see' and 'Mina need key' for 'Mina needs a key'). The scarcity of statives in RIs also suggests that eventives and statives are not in 'free variation' in RI clauses.

32 For specific examples of each type of verbs, see Castro (2002) or Margaret Deuchar and Suzanne Quay, Bilingual Acquisition Theoretical Implication of a Case Study (Oxford: Oxford University Press, 2000). 
Table 5. Temporal and aspectual interpretation of finite forms

\begin{tabular}{|l|c|c|c|c|}
\hline File number & Verbs & Past & Present & Future \\
\hline \multirow{2}{*}{ File 5 } & Statives & 0 & 0 & 0 \\
\cline { 2 - 5 } & Eventives & 2 & 0 & 0 \\
\hline \multirow{2}{*}{ File 6 } & Statives & 0 & 0 & 0 \\
\cline { 2 - 5 } & Eventives & 2 & 0 & 0 \\
\hline \multirow{2}{*}{ File 8 } & Statives & 0 & 3 & 0 \\
\cline { 2 - 5 } & Eventives & 2 & 0 & 0 \\
\hline \multirow{2}{*}{ File 11 } & Statives & 0 & 0 & 0 \\
\cline { 2 - 5 } & Eventives & 0 & 0 & 0 \\
\hline Total Eventives & & $6(66 \%)$ & 0 & 0 \\
\hline Total Statives & & 0 & $3(33 \%)$ & 0 \\
\hline
\end{tabular}

Source: Based on Castro, p. 22.

Now, we will proceed with analysis of inflected verbs. Although raw numbers are quite small, we find, once again, that past tense irregular morphology (15 forms) precedes 3PS -s morphology emergence ( 3 forms). Table 5 presents the information about $A$ ktionsart and temporal interpretation of finite predicates. In this group there is a higher number of eventive verbs (denoting action or change) which in this case also express past reference (Examples: 'got cake' for 'I got cake' and 'told him' for 'I told him'). The child uses eventive verbs such as 'get,' 'tell,' 'make' and 'put.' Finite 3PS predicates are statives in which 'go' is given the meaning of 'belong to'. Recall the syntactic representation in Figures 1 and 2 above. The previous discussion and these figures show that my analysis yields similar results to those of Wijnen; that is, inflected predicates show an agreement between this inflection and their temporal reference; otherwise, lack of inflection coincides with free temporal reference.

Furthermore, aspectual interpretation of non-finite eventive predicates can also be considered. Consider the information in Table 6 below: 
Table 6. Aspectual interpretation of non-finite forms

\begin{tabular}{|l|c|c|c|c|}
\hline File number & Ongoing & Future/modal & Habitual & Terminative \\
\hline File 3 & 0 & 1 & 0 & 0 \\
\hline File 5 & 8 & 11 & 0 & 1 \\
\hline File 6 & 3 & 1 & 0 & 0 \\
\hline File 8 & 3 & 2 & 0 & 1 \\
\hline File 11 & 0 & 0 & 1 & 0 \\
\hline Total & 14 & 15 & 1 & 2 \\
\hline Percentages & $44 \%$ & $47 \%$ & $3 \%$ & $6 \%$ \\
\hline
\end{tabular}

Source: Castro, p. 24.

The distribution of the non-finite forms with ongoing interpretation (where the moment of speech precedes the event time $\mathrm{S}<\mathrm{E}$ ) and future interpretation (when the moment of speech overlaps with the event time $\mathrm{E}=\mathrm{S}$ ) is even. This means that the aspectual interpretation of RIs is essentially free between 'ongoing' and 'future/ modal' interpretation. From the remaining utterances only two forms have a 'terminative' interpretation and only one form has a habitual interpretation. No generic interpretation is found. See examples below for these aspectual interpretations.

(10)

Ongoing interpretation

Me make Rayna' tea (File 5)

'I am making Rayna's tea'

(11)

Future Modal Interpretation

Mina do it (File 3)

'I will do it'

(12) Habitual Interpretation

They pop out (File 11) (They:coins) 
(13) Terminative interpretations

Rayna touch floor (File 5)

'Rayna touched the floor'.

All past forms used by Mina have a terminative (telic) aspectual intepretation. So, we see that while the non-finite aspectual interpretation is free (ongoing, future, past habitual) the inflected predicates are used with terminative interpretation (plus the verb 'get' which has punctual semantics).

In conclusion, there is evidence for some very interesting correlations in these data. The non-finite predicates are predominantly eventives with free temporal and aspectual reference. The finite predicates are both eventives and statives with different temporal and aspectual reference. Although non-finite as well as finite forms are used by the child, it cannot be concluded that they are in 'free variation.' These results are similar to those of Wijnen in the following aspects: first, it was likewise observed that eventive verbs have free aspectual reference, although 'ongoing' or 'future' interpretation tend to dominate. Second, finite forms have a fixed temporal reference. Finally, finite statives have present reference in his study as well as in mine.

A contrast is also present. Wijnen found a correlation between stative verbs and present tense reference. ${ }^{33}$ In this analysis, although there is also a correlation between present tense reference and stative verbs, there is also a different correlation between temporal reference and eventive verbs, which are given mainly a past temporal interpretation. It would be interesting to determine why in the case of the English/Spanish-speaking bilingual child more than one correlation can be established.

$\overline{33 \quad \text { Wijnen. } 16 .}$ 


\section{Optional Infinitive Stage in the Acquisition of Spanish}

This section presents the analysis of Spanish data in order to determine whether there is evidence of the Optional Infinitive Stage. Table 7 presents the distribution of verbs according to finiteness; a discussion about the properties of verbal predicates follows:

Table 7. Distribution of finite and non-finite verbs in Spanish

\begin{tabular}{|l|c|c|c|c|c|}
\hline $\begin{array}{l}\text { File } \\
\text { number }\end{array}$ & $\begin{array}{c}\text { Inflected } \\
\text { forms }\end{array}$ & $\begin{array}{c}\text { Infinitival } \\
\text { forms }\end{array}$ & $\begin{array}{c}\text { Present } \\
\text { participle }\end{array}$ & $\begin{array}{c}\text { Future } \\
\text { va + a +(verb) }\end{array}$ & Modals \\
\hline File 1 & 1 & 0 & 0 & 0 & 0 \\
\hline File 3 & 8 & 0 & 0 & 0 & 0 \\
\hline File 4 & 2 & 2 & 0 & 0 & 0 \\
\hline File 6 & 3 & 1 & 0 & 0 & 0 \\
\hline File 7 & 26 & 2 & 8 & 7 & 6 \\
\hline File 9 & 46 & 0 & 2 & 10 & 4 \\
\hline File 10 & 22 & 0 & 2 & 5 & 1 \\
\hline Total & 108 & 5 & 12 & 22 & 11 \\
\hline Percentage & $68 \%$ & $3 \%$ & $8 \%$ & $14 \%$ & $7 \%$ \\
\hline
\end{tabular}

Source: Castro, p. 27.

There is an overwhelming majority of finite forms in the data. There are $108(68 \%)$ finite verbs as opposed to only 5 (3\%) nonfinite forms (two infinitives with a clitic and three participles without the auxiliary 'estar' (be)). ${ }^{34}$ If we follow Wexler, who defines the Optional Infinitive stage as the period when children use infinitives as root predicates, then we would have to conclude that there is no

34 Present participle, future and modal forms are also present in the data: however, they will not be part of the analysis. For examples and analysis, see Castro (2002) or Quiad (2001). 
evidence of the Optional Infinitive stage in Spanish. Mina starts out by using inflected verbs. See the contrast in the following examples ${ }^{35}$ : (14) Non finite forms

a. "comiendo" (file 4)

"Él está comiendo"

b. "limpiarlo con agua" (file 6)

"Voy a limpiarlo con agua"

c. "Woof abrirlo" (file 7)

"Woof va a limpiralo"

(15) Correctly inflected forms

a. "Más tengo más" (file 3)

"Tengo más"

b. "Aquí pasa" (file 3)

"¿Qué pasa aquí?"

c. "Granny sienta" (file 3)

"Granny se sienta"

Although in File 4 there is an equal distribution of finite and non-finite forms, the numbers are very small (2/2), and there is no apparent significant increase in the number of non-finite forms in the subsequent files. A question arises: Does this mean that there is no Optional Infinitive stage in Mina's language? The Spanish data will require further analysis before a conclusion is reached. Considering Aktionsart information there is a very even distribution (Table 8

35 The phrases above stand for: 14a. "he is cating": 14b. "I will clean it with water": 14c. "Woof will open it": $15 \mathrm{a}$. "I have more": $15 \mathrm{~b}$. "What is happening"; 15c. "Granny sits down". 
below). We find an almost even split between 55 eventive verbs (51\%) as opposed to 53 stative verbs (49\%). Wijnen found very similar results for Dutch (See Table 1 above, and Table 8 below). The next step is to analyze the aspectual distribution of finite forms according to the type of verb.

\section{Table 8. Finite Spanish verbs interpretation}

\begin{tabular}{|l|c|c|}
\hline File & Eventive & Stative \\
\hline File 1 & 1 & 0 \\
\hline File 3 & 4 & 4 \\
\hline File 4 & 1 & 1 \\
\hline File 6 & 3 & 0 \\
\hline File 7 & 13 & 13 \\
\hline File 9 & 26 & 20 \\
\hline File 10 & 7 & 15 \\
\hline Total & 55 & 53 \\
\hline Percentage & $51 \%$ & $49 \%$ \\
\hline
\end{tabular}

Source: Castro. p. 30.

A very particular behavior can be observed in some of the inflected verbs. Due to the inflectional complexity of Spanish verbs, it is normal to expect some agreement errors in the early grammars of children. This is indeed the case in Mina's speech, which presents agreement errors in a specific syntactic context. According to the data, even though not all utterances containing an overt subject have subjectverb agreement errors, every time agreement errors occur in the root clauses these sentences contain an overt subject. A total of 15 (15\%) sentences contain errors of agreement. Some of the examples are provided in (16). The information in parentheses was reconstructed based on the context and previous sentences. 
$(16)^{36}$

a. Mamá tienes (una carta) (File 4)

Mamá tener- 2PSg (una carta)

"Mamá tiene una carta."

b. Yo puso (la bolsa de letras) aquí (File9)

Yo poner 3PSg (la bolsa de letras) aquí

"Yo voy a poner la bolsa de letras aquí."

The analysis shows that there is only one instance where there is no overt subject and where there is a lack of agreement with the non-overt subject, as in (17).

(17)

$$
\begin{aligned}
& \text { a. } \quad \text { puso eso (File 9) } \\
& \text { poner-Past-3PSg eso } \\
& \text { "Yo puse eso" }
\end{aligned}
$$

The remaining examples that present cases of subject-verb 'misagreement' have an overt subject in their constructions, so further analysis is required. The temporal interpretation of 'misagreement utterances' is also an important factor. Spanish has a particular way of assigning temporal interpretation to a verb. It could be Past (either Preterit or Imperfect), Present or Future (either synthetic, marked by a suffix on the verb, or periphrastic, va $+a+$ infinitive verb). Mina uses only Preterit to express a Past action (there is no evidence of Imperfect forms in her productions). She uses only the periphrastic future to express future events. However, present tense forms in her speech can have a future reference that we will call 'ultra-immediate future.' These forms refer to an action that will take place exactly after the child says the utterance. They are not considered an 'ongoing act' because the moment of speaking ( $\mathrm{S}$-time) is not included in the

36 (16) a. "Mom has 3PS a letter"; b. "I will put 3PS (the bag of letters) here. (17) a "I put 3PS that": (18) "I will draw" 3PS. 
action expressed by the 'misagreeing' verb. (E-time). This is a very interesting (and important) discovery because all 'misagreeing' forms in Mina's data have an 'ultra- immediate future' interpretation, as in (18): (18)
a. *dibuja yo
dibuja - 3PSg yo
"Yo voy a dibujar eso"

She uses ultra-near future to express particular roles that participants are to play in an activity, to describe events or indicate an action that will take place right after the sentence is uttered (18). For all of the previous action possibilities, Mina uses verbs in present tense; there is only one case where she uses a past tense to express ultra-near future. In Spanish adult speech, this 'ultra-immediate' future is found in the same contexts mentioned above. For example, imagine a situation in which a family has just moved to a new house and the mother describes what is going to happen next while someone assigns certain task to each person in the group; then they start working, as in (19): (19)

a. Carol limpia las sillas, Carlos pinta la mesa y yo preparo la cena.

Carol clean3PSg the chairs, Carlos paint3PSg the table and I fix IPSg the dinner 'Carol will clean the chairs, Carlos will paint the table and I will fix dinner'

In this analysis we also considered whether eventive and stative 'misagreeing predicates' differ in temporal interpretation. For eventive verbs showing subject-verb agreement errors there is a correlation between these verbs and the 'ultra immediate future' temporal interpretation. 'Misagreeing' stative verbs, on the other hand, are limited to 'present' temporal interpretation. ${ }^{37}$ Based on this information a question arises: Could the 'misagreeing predicates' in the Spanish data be the counterparts of RIs in child Dutch and English? If this is

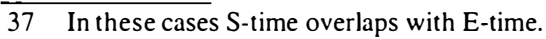


Table 9. Spanish subject-verb agreement error/eventive-stative verbs (all ultra-near future)

\begin{tabular}{|c|c|c|}
\hline File & Sentence gloss & $\begin{array}{l}\text { Inherent semantics } \\
\text { of the verb }\end{array}$ \\
\hline File 4 & $\begin{array}{l}\text { *dibuja yo } \\
\text { draw-3PSg, I } \\
\text { "I will draw" } \\
\text { "Yo voy a dibujar" }\end{array}$ & Activity \\
\hline File 7 & $\begin{array}{l}\text { "mummy tengo este(pieza de lego) } \\
\text { mummy have3PSg this (piece of lego) } \\
\text { "Mummy has this (piece of lego)" } \\
\text { "Mummy tiene esa pieza" }\end{array}$ & State \\
\hline File 7 & $\begin{array}{l}\text { *mi come este (queque) } \\
\text { Me eat } 3 \text { PSg this (cake) } \\
\text { "I will eat this (cake)" } \\
\text { "Yo voy a comer eso" }\end{array}$ & Accomplishment \\
\hline File 7 & $\begin{array}{l}\text { *mi hacen otra (casa) } \\
\text { me make3PPl another (house) } \\
\text { "I will make another (house)" } \\
\text { "Yo voy a hacer eso" }\end{array}$ & Accomplishment \\
\hline File 9 & $\begin{array}{l}\text { "yo puso (la bolsa de letras) aquí } \\
\text { I put3PSg (the bag of letters) here } \\
\text { "I will put (the bag of letters) here". } \\
\text { "Yo voy a poner la bolsa de letras aquí." }\end{array}$ & Achievement \\
\hline File 9 & $\begin{array}{l}\text { *si yo va (a hacer un tren) } \\
\text { Yes, I go-3PSg (to make a train) } \\
\text { "Yes, I will (make a train)", } \\
\text { "Sí. yo voy a hacer un tren" }\end{array}$ & Accomplishment \\
\hline File 9 & $\begin{array}{l}\text { *tú cuida (de mi) } \\
\text { you take care3PSg (of me) } \\
\text { "You will take care of me" } \\
\text { "Tú vas a cuidar de mí" }\end{array}$ & Activity \\
\hline File 9 & $\begin{array}{l}\text { *(cuando yo regreso de Miami) } \\
\text { yo va en otro avión } \\
\text { (when I come back from Miami) } \\
\text { I go3PSg in another plane } \\
\text { "I will go in another plane" } \\
\text { "yo voy a ir en otro avión" }\end{array}$ & Activity \\
\hline
\end{tabular}

Adapted from: Castro. p. 35. 
the case, then these verbs should also be found in other sentences where they are given correct inflection. If they are correctly inflected sometimes, but the inflection fails in other cases, so we could propose that RIs are disguised as 'misagreeing' verbs in the acquisition of finiteness in Spanish. If this is the case, then they should be added to the RIs group (infinitives and participles) and would represent $18 \%$ of the data analyzed. In Table 9 , we have followed the typology proposed by Vendler, where different predicate types can be assigned the aspectual classification of activity, accomplishment, achievement or state, depending on the different semantics of the verb. ${ }^{38}$ We have used this categorization and the tests from Shirai and Andersen to determine whether there is some type of pattern in these sentences. ${ }^{39}$

The 'misagreeing' predicates also include statives, although the only verb used in this case is the verb 'tener' ('have'). The data show evidence of all four types of verbs that Vendler proposes. Table 10 presents cases where the same verbs that present errors of agreement are also used in combination with correct inflection. Cases (a), (b) and (d) are not present in any other utterances. Example (c) presents the verb 'hacer' (to make), and there are examples where this verb is used with the appropriate inflection, as is the case of the example in Table 10. Example (d) only presents three cases, all with 'misagreeing' form. Example (e) is evidence of sentences in which the verb is correctly inflected, as is also the case for (f). Finally, in the case of ( $\mathrm{g}$ ) there are also examples in which inflection matches subject and verb. In summary, the verbs that are both correctly and incorrectly inflected are 'hacer' (make), 'ir' (go), 'cuidar' (take care of) and 'tener' (have). All of these are 'variable behavior' verbs because they can appear as activities or accomplishments (except for 'have,' which is a stative verb).

38 Zeno Vendler, Linguistics in Philosophy. (Ithaca. NY: Cornel University Press, 1967).

39 Yasuhiro Shirai and Roger Andersen, "The Acquisition of Tense-Aspect Morphology: A Prototype Account," Language, 71 (1995) 743-761. 
Table 10. Correct subject-verb agreement inflections

\begin{tabular}{|c|c|c|}
\hline Verbs & Predicate type & Examples and gloss Transcription \\
\hline $\begin{array}{l}\text { a. to draw } \\
\text { 'hacer' }\end{array}$ & Activity & No other relevant examples about this case. \\
\hline $\begin{array}{l}\text { b.To eat } \\
\text { 'comer' }\end{array}$ & Accomplishment & No other relevant examples of this case. \\
\hline $\begin{array}{l}\text { c.To make } \\
\text { 'hacer' }\end{array}$ & Accomplishment & $\begin{array}{l}\text { Otro hago café (file 9) } \\
\text { Another make 1PSg coffee } \\
\text { 'I will make another coffee' } \\
\text { "Voy a hacer otro café" }\end{array}$ \\
\hline $\begin{array}{l}\text { d.to put } \\
\text { 'poner' }\end{array}$ & Achievement & No other relevant examples about this case. \\
\hline $\begin{array}{l}\text { e.Togo } \\
\text { 'ir' }\end{array}$ & Accomplishment & $\begin{array}{l}\text { Mamá y papá van (a) Londres (File 9) } \\
\text { Mom and Dad go (3PPl (to) London } \\
\text { "Mom and dad will go to London" }\end{array}$ \\
\hline $\begin{array}{l}\text { f. To tale care of } \\
\text { 'cuidar' }\end{array}$ & Activity & $\begin{array}{l}\text { Yo cuido (al) perrito (File 9) } \\
\text { btake care of (of the) little dog } \\
\text { "I will take care of the little dog" }\end{array}$ \\
\hline $\begin{array}{l}\text { g. To have } \\
\text { 'tener' }\end{array}$ & Stative & $\begin{array}{l}\text { Tengo cartas (File 9) } \\
\text { Have 1PSg letters } \\
\text { "I have letters" }\end{array}$ \\
\hline
\end{tabular}

Adapted from: Castro, p. 36, 38.

Another consideration deals with whether there is some difference in the distribution of correctly agreeing verbs that have overt subject and ultra-near future reference. This will enable us to determine whether the pattern of correct or wrong agreement is limited to a specific aspectual type of eventive verbs. Consider the information in Table 11 below. 
Table 11. Correct agreement-overt subject with ultra-near future interpretation

\begin{tabular}{|l|c|c|c|c|}
\hline File number & Activity & Accomplishment & Achievement & States \\
\hline File 3 & 0 & 0 & 1 & 0 \\
\hline File 6 & 0 & 1 & 0 & 0 \\
\hline File 7 & 0 & 2 & 2 & 0 \\
\hline File 9 & 2 & 0 & 1 & 0 \\
\hline File 10 & 0 & 0 & 1 & 3 \\
\hline Total / Percent & $2(16 \%)$ & $3(23 \%)$ & $5(38 \%)$ & $3(23 \%)$ \\
\hline
\end{tabular}

Source: Castro. p. 39.

Among the 13 verbs, we find some that belong to each of the four types of interpretation: Achievement, Accomplishment, Activity and State. There is a slight majority of achievement verbs (38\%), but among all of them the rest of interpretations are also present. The verbs in Table 10 have the particular feature that allows them to change the aspectual class depending on the arguments or complements that these verbs take. For example, the predicate including the verb 'ir' (go) in the following examples can have Accomplishment or Activity interpretation. See (20) below:

(20)

(a) Yo voy a Miami

I go to Miami

'I will go to Miami'

(Accomplishment)

(b) Yo voy en avión

I go by plane

'I will go by plane'

(Activity)

Other verbs belonging to group that is correctly optionallyinflected in Mina's speech behave the same way. The restriction of 
agreement errors to 'aspectually transient' verbs, discussed by Verkuyl, ${ }^{40}$ can be determined only if we consider Vendler's typological distinction, only a stative/eventive distinction would not suffice. ${ }^{41} \mathrm{~A}$ more detailed analysis was necessary to determine the variability of their behavior with respect to the use of inflection. So our suggestion that 'misagreeing' predicates play the role of 'Optional Infinitives' is possible, given the evidence above, which would indicate that Mina optionally uses certain verbs in an incorrectly inflected form rather than a non-finite form during the developmental period in question. We propose that there is a stage in the acquisition of finiteness in Spanish in which children may use 'misagreeing' finite forms as 'Optional Infinitives.' Further research is necessary to determine why this takes place, and the extent to which this claim is valid. The morphological inflectional paradigm of Spanish is very different if we compare it to the languages analyzed by Wexler. Verb conjugation in Spanish, German, and French differs in several aspects. Moreover, one difference at the syntactic level among these languages is also important. Spanish is a pro-drop language, in the sense that the subject does not need to be overt (thus children are more sensitive to inflection which may lead to preference of inflected forms over infinitive forms); German, French and English, on the other hand, are not pro-drop languages.

\section{Crosslinguistic Differences and the Status of INFL}

Although there are crosslinguistic similarities in the languages analyzed, this analysis has demonstrated that there are also differences. English, Dutch and Spanish exhibit interesting differences in finiteness correlation. Consider Table 12 below:

40 Henk VerKuyl. On the Compositional Nature of Aspects (Dordrech: Reidel, 1972).

41 Wijnen had limited his study to this distinction. 


\section{Table 12. Finiteness from a crosslinguistic perspective}

\begin{tabular}{|l|c|c|c|}
\hline & Spanish & English & Dutch \\
\hline Finite & $93(85 \%)$ & $16(30 \%)$ & $699(27 \%)$ \\
\hline Non finite & $17(15 \%)$ & $38(70 \%)$ & $1883(73 \%)$ \\
\hline Total & 110 & 54 & 2582 \\
\hline
\end{tabular}

Source: Castro, p. 43.

Looking at the percentages, it is evident that English and Dutch are very similar. Although raw numbers are significantly different, percentages are quite close. English finite forms represent $30 \%$ while for Dutch they are 27\%; for non-finite forms there is 70\% in English and $73 \%$ in Dutch. In Spanish results, on the other hand, present a very different picture. In the finite subgroup there is $85 \%$, as opposed to $15 \%$ of non-finite forms. If we look at the percentages and compare Spanish and Dutch, for example, we can see that there is a difference of 58\% in the case of the finite forms and $56 \%$ in the case of the nonfinite forms. Now some questions arise: What are the causes of these very marked cross-linguistic differences? Why do these languages call for use non-finite predicates in such different proportions in their productions?

Hoekstra and Hyams $(\mathrm{H} \& \mathrm{H})$ analyzed the rate of RI usage in different languages. ${ }^{42}$ When comparing their results for the Catalanspeaking children with the results that we obtained in the Spanish section for Mina, some similarities are evident. RIs have a rate of about $0.02 \%$ in comparison to the inflected predicates used in the same environments. $\mathrm{H} \& \mathrm{H}$ also examined the rate of agreement errors in the group of predicates that are inflected. The difference seems to increase if we consider the error agreement rate, which goes from less than 3\% for Catalan children to 14\% for the bilingual Spanish/ English child. Although the percentage of correct agreement is still

$\overline{42}$ Teun Hoekstra and Nina Hyams, “Aspect of Root Infinitivals," Lingua. 106 (1998) 81-112. 
significant in both languages, it is evidently more significant in Catalan as seen in the distribution in Table 13 below.

Table 13. Use of RIs and error agreement in cross-linguistically

\begin{tabular}{|l|c|c|c|c|c|}
\hline Language & Child & Age & \% RIs & Agreement & $\begin{array}{c}\text { Source } \\
\text { error rate }\end{array}$ \\
\hline Catalan & Guillen & $1 ; 11-2 ; 6$ & $0.03 \%$ & $1.2 \%$ & $\mathrm{H} \& \mathrm{H}(1998)$ \\
\hline Catalan & Marti & $2 ; 0-2 ; 5$ & $0.02 \%$ & $2.3 \%$ & $\mathrm{H} \& \mathrm{H}(1998)$ \\
\hline Spanish & Mina & $1 ; 9-2 ; 6$ & $0.02 \%$ & $14 \%$ & Castro (2002) \\
\hline
\end{tabular}

Adapted from: Castro, p. 45.

In the following section we propose a different 'optionality effect' to account for the Spanish data. If Catalan allows present tense morphology to express an 'ultra near future' interpretation, as in Spanish, then we may propose that a similar 'optional effect' could be predicted for Catalan, both being romance languages sharing similarities in other areas as well. Researchers working with Catalan data should look for similar effects to see if this 'mismatch' between tense morphology and temporal interpretation is also present.

\section{Status of Infl}

The different proposals mentioned at the beginning of this paper refer to the content of Infl during stage $S_{0}$. Poeppel and Wexler's full specification proposal claims that Infl already has all the necessary Tense and Agreement features. Could it be, then, that Infl is absent or 'misagreeing' during the 'Optional Infinitive' stage due to phonological reasons? After analyzing the English data we found that, aside from the 3PSg missing -s, there are only three predicates lacking some phonological segments ${ }^{43}$ (based on the phonetic transcription

43 a. Min(a) need key ('Mina needs a kcy); b. Mina take shower ('Mina takes a shower'); c. bu she hasn ('but she hasn't'). 
provided by CHILDES). Throughout the data there are some phonological segments that are sporadically missing (as is the case of 3PSg $-\mathrm{s}$ mentioned). This suggests that Mina has a quite late emergence of final/s/. According to Wexler, the presence of this marker is evidence of the acquisition of Infl. ${ }^{44} \mathrm{We}$ analyzed the Spanish data to determine if this segment is missing in this language too. ${ }^{45}$

The analysis shows that $-\mathrm{s}$ is missing in most $2 \mathrm{PSg}$ and $1 \mathrm{PPl}$ as well as in most plural nouns. The segment appears more consistently in nouns after file 7 , and in third person singular present verbs after file 8. In the Spanish data, $/ \mathrm{s} /$ is absent in both verbs and nouns in file 9 and it appears again in nouns in file 10. This means that before file 7 the child has a problem pronouncing /s/ and that this segment only begins to appear in a somewhat more consistent manner after file 7 . So, it could be considered a problem in the phonological development of the child. This finding has an important implication for the acquisition of Infl in Mina's bilingual grammar. Wexler and Wijnen, mentioned above, also suggest that the presence of -s marker is directly associated with finiteness features. However, my analysis shows that one must also consider phonological factors when dealing with absence of segments such as $/ \mathrm{s}$, particularly in English where the verbal morphology is impoverished. The conclusions on the Spanish data could not, however, be extended to most eventive verbs in this study, since the contexts where they occur do not require $-\mathrm{s}$, nor does it account for the Dutch data.

This information led us to exclude the possibility of a full specification of Infl in which case the optionality effect is related to morphological or phonological reasons. Certainly, we cannot argue that Infl is missing because in both Spanish and English there is evidence of its presence in instances containing correct tense and agreement features. Therefore, the data analyzed suggests that certain

44 Wexler, 307.

$45 \mathrm{/s} /$ should appear in Spanish at the end of 2PSg. 1PPI. and in plural nouns. 
functional categories have been underspecified. Infl is underspecifiied in English, meaning that there are morphological and syntactic processes taking place in this projection, which have not been clearly determined and are optionally used. In the case of Spanish, there is underspecification of CP.

In Wijnen's results represented in Figure 2 above, we presented the idea that tense specification in TP matched the temporal interpretation given in CP through a tense operator (TO). In the case of Spanish it would appear that when there is 'mismatch' between the syntactic tense features and specification given by the TO, we obtain a misagreeing predicate in the child's production. The 'misagreeing' predicates $(15 / 54 \%)$ alternate with adult-like predicates $(13 / 46 \%)$ in this syntactic context at an equal rate, thus suggesting an interesting possibility that an optionality effect in Spanish is morphologically expressed through incorrect agreement (mostly 3PSg) instead of infinitival morphology, as for Dutch. Future studies need to validate this claim. Figure 3 below represents this idea:

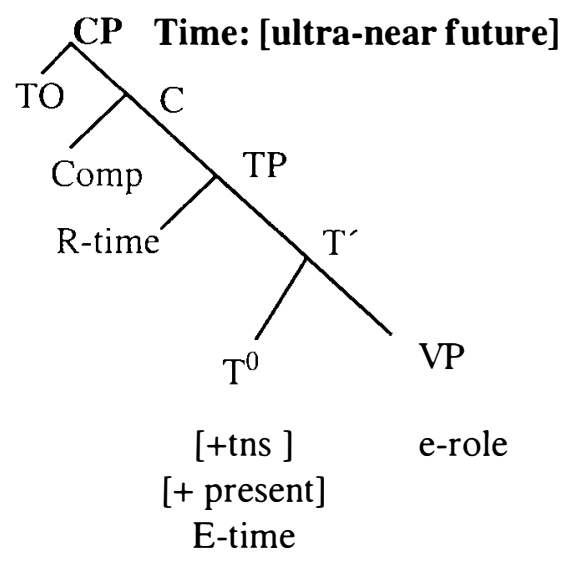

Figure 3. Mismatch of features and the optionality effect 
This optionality effect appears when there is an overt subject and the temporal interpretation that is required is that of ultra-near future expressed through present tense. Optionality in English or Dutch results when there is no specification for tense in TP and the sentences containing RIs are given present, past or future interpretation. In the case of Spanish there is a specification for tense in the TP, and the TO has to provide an 'ultra near future' interpretation; the optionality here is present in relation to the ability to provide the correct or incorrect agreement features in the verb. The trees presented in the present analysis differ in that there is an underspecification of TP in English (Fig 1 above) seen in the use of RI, since when there is no specification for Tense, free temporal reference takes place. Moreover, there is an underspecification of the CP in Spanish (seen in the optionality of agreement) when there is a mismatch of tense features and the temporal interpretation provided through TO. Our research shows that the grammar of this bilingual child develops in two distinct ways, thus supporting the 'two separate systems' hypothesis. ${ }^{46}$

In conclusion, there is evidence for an Optional Infinitive in both the Spanish and English data. In English it is expressed through RIs; and in Spanish through the use of 'aspectually variable' verbs that appear as 'misagreeing' predicates. The data analyzed for this paper has implications for approaches to the Optional Infinitive stage. At the same time it has implications for the status of Infl during the period of bilingual acquisition studied, meaning that languages may vary in the morphological forms that children use as non-finite predicates during the 'optional infinitive stage.' It is also important to consider crosslinguistic differences (expressed through aspectual characteristics) during this stage of children's developing grammar, for which an in-depth analysis that goes beyond Wexler's classification of finiteness or Wijnen's or eventive/stative distinction is needed. The findings of this study should be examined in further studies to determine its validity and application to other cases.

46 F. Genesse. "Farly hilingual development: One Way or Two?" Journal of Child Languages, 22 (1989) 611.0 .31 